\title{
Analysis Performance Bank of Government Bank at PT Bank Tabungan Negara (Persero) Tbk Period of 2015 - 2018
}

\author{
Harun Faizal ${ }^{1 *}$, Riska Rosdiana ${ }^{2}$ \\ ${ }^{1}$ Faculty of Economics and Business-Universitas Muhammad Husin Thamrin \\ 2Faculty of Economics and Business - Universitas Mercu Buana \\ ${ }^{*}$ Corresponding Author \\ Harun Faizal
}

Article History

Received: 10.08 .2019

Accepted: 26.08 .2019

Published: 25.09.2019

\begin{abstract}
This study aims are analysis of performance Bank at PT Bank Tabungan Negara (Persero) Tbk by implementing the RGEC (Risk Profile, Good Corporate Governance, Earning, Capital) method 2015 until 2018 banks through a composite analysis. The purpose of this study is to analyze the performance Bank at PT Bank Tabungan Negara (Persero) Tbk by implementing the RGEC (Risk Profile, Good Corporate Governance, Earning, Capital) method 2015 until 2018. The method used in this study is RGEC (Risk Profile, Good Corporate Governance, Earning, Capital). The result are the performance ratio of Based on result and discussion so the conclusion is performance bank of PT Bank Negara Indonesia (Persero) the value of determination or composite since 2015 until 2018 is healthy, and performance bank used RGEC method as follows: 1) Risk Profile are a). Non Performing Loan (NPL) is in 2015 is healthy, NPL in 2016 is very healthy,NPL in 2017 is very healthy, NPL in 2018 is very healthy. b) Loan to Deposit Ratio (LDR) is in 2015 unwell, LDR in 2016 is unwell, LDR in 2017 is unwell, LDR in 2018 is unwell. 2) Good Corporate Governance (GCG) is performance GCG in 2015 is healthy, GCG in 2016 is healthy, GCG in 2017 is healthy, GCG in 2018 is healthy. 3) Earning are a) Return on Assets (ROA) is RAO in 2015 is very healthy,ROA in 2016 is very healthy, ROA in 2017 is very healthy, ROA in 2018 is healthy. b) Net Interest Margin (NIM) is NIM in 2015 is very healthy, NIM in 2016 is very healthy, NIM in 2017 is very healthy, in 2018 is very healthy. 4) Capital for Capital Adequacy Ratio (CAR) is in 2015 is very healthy, CAR in 2016 is very healthy CAR in 2017 is very healthy, CAR in 2018 is very healthy.
\end{abstract}

Keywords: Bank Health and the RGEC Method (Risk Profile, Good Corporate Governance, Earning, Capital).

\section{INTRODUCTION}

Financial Services Authority Circular number 14 / SEOJK.03 / 2017 dated March 17, 2017 concerning Rating of Commercial Bank Soundness in point III.1 Procedure for Assessing the Soundness of Commercial Banks Individually Assessment of Soundness Level of Commercial Banks Individually includes an assessment of risk profile factors, Governance, profitability and capital [1]. An healthy bank is a bank that can perform its functions properly. In other words, a healthy bank is a bank that is able to keep and maintain the trust of the community, can do the intermediassi function, it can help smooth the payment as well as lalulitas can be used by the Government in carrying out a wide range of its policies, especially monetary policy [2].

PT Bank Tabungan Negara (Persero) Tbk. again won the title as the Best Bank in 2018. The predicate was achieved by the company's success in leapfrogging the position of assets over the past six years and successfully penetrating the fifth rank of the bank with the largest asset control [3], but based on 2015 and 2016 financial statement data in the assessment of the soundness of banks conducted by economic news on the best banking award, BTN bank only ranks healthy banks in second place only. The following data from the economic news that The Bank is rated as Healthy in the Book Category III with assets above IDR 100 Trillion 1. PT Bank HSBC Indonesia, 2. PT Bank Tabungan Negara (Persero) Tbk, 3. PT BPD West Java and Banten Tbk, 4. PT Bank Maybank Indonesia Tbk, 5. PT Bank Permata Tbk[4].

This study aims to analyze of performance bank at PT Bank Tabungan Negara Tbk with RGEC (Risk Profile, Good Corporate Govermance, Earning, and Capital) of 2015 until 2018 period.

Copyright @ 2019: This is an open-access article distributed under the terms of the Creative Commons Attribution license which permits unrestricted use, distribution, and reproduction in any medium for non commercial use (NonCommercial, or CC-BY-NC) provided the original author and source are credited. 
Based on the last reseach are Riadi, et al. [5] that the soundness of banks in 2013 to 2015 from the risk profile aspect is classified as very healthy, Good Corporate Governance is quite healthy, earnings are very healthy, and Capital is very healthy. Kusnanto [6] that the Bank's Health Level in terms of RGEC at Sharia Commercial Banks in the period of 2013, 2014, and 2015 are in healthy criteria, so it is considered very capable of facing significant negative impacts from changes in business conditions and other external factors. Rahmaniah and Wibowo [7] that the year 2011 to 2013 on the third BUS (Islamic Banks) nothing is declared unhealthy and potentially high financial distress, the three buses experienced a decline in the performance of earnings as measured by ROA and ROE and liquidity ratios that FDR, but the decline no significant effect and does not experience the potential of high financial distress. Helsinawati et al. [8] that the assessment financial performance of PT. Bank Bukopin Tbk before and after the application of branchless banking is not difference and not significant, but is not fixed value. Widyanto [9] that the comparison ofthe performance of DKI Bank and PT BPD Jawa Tengah in 2017 are not significant difference; the comparison of the PT BPD Central Java's performance is not significant difference for 2016 and 2017, but the comparison the The performance of Bank DKI for 2016 and 2017 is significant difference. The implementation of Circular Letter Number 14/SEOJK.03/2017 regional development banks period 2016 (before) and 2017 (after), shows that the assessment of financial performance of PT BPD Central Java are not significant difference, however the assessment of financial DKI Bank's performance is a significant difference. In 2017 after the implementation of Circular Letter Number 14/SEOJK.03/2017 the results show that the comparison of the performance of PT BPD Jawa Tengah and Bank DKI are not significant difference. Permana D (10) that strategic clarity in term of align with vision, priority of strategy and scope of strategy have positive significant impact on strategy implementation success in Indonesian Islamic banking. The implications of these findings are further elaborated.

\section{MATERIALS AND METHODS \\ Bank Health}

Bank health is the competence of a capable bank carrying out its activities in accordance with applicable regulations. So Bank health is important for all parties involved and has an interest in the bank [11].

Based on Bank Indonesia circular number 13/24/ DPNP of 2011 concerning rating of soundness of bank [12] as follows:

\section{Risk Profile}

Non Performing Loans (NPL)

Scale Criteria

- $\quad 0 \%<\mathrm{NPL}<2 \%$ Very Healthy (SS)

- $2 \%$ PLNPL $<5 \%$ Healthy $(\mathrm{S})$

- $5 \%$ PLNPL $<8 \%$ Quite Healthy (CS)

- $8 \%$ PLNPL $<11 \%$ Unwell (KS)

- $\mathrm{NPL}>11 \%$ Not Healthy (TS)

Loan to Deposit Ratio (LDR)

Scale Criteria

- $50 \%<\mathrm{LDR} \leq 75 \%$ Very Healthy (SS)

- $75 \%<\mathrm{LDR} \leq 85 \%$ Healthy (S)

- $85 \%<\mathrm{LDR} \leq 100 \%$ Quite Healthy (CS)

- $100 \%<\mathrm{LDR} \leq 120 \%$ Unwell (KS)

- LDR> $120 \%$ Not Healthy (TS)

\section{Good Corporate Governance (GCG)}

Based on Bank Indonesia circular number 15/15 / DPNP of 2013 [13] concerning Rating of soundness of banks is GCG Scale Criteria as follows

$$
\begin{array}{ll}
\text { - } & 1=\text { Very Healthy (SS) } \\
\text { - } & 2=\text { Healthy (S) } \\
\text { - } & 3=\text { Quite Healthy (CS) } \\
\text { - } & 4=\text { Unwell (KS) } \\
\text { - } & 5=\text { Not Healthy (TS) }
\end{array}
$$

\section{Earning}

Return on Assets (ROA)

Scale Criteria

- $\mathrm{ROA}>1.5 \%$ Very Healthy (SS)

- $1.25 \%<\mathrm{ROA} \leq 1.5 \%$ Healthy $(\mathrm{S})$

- $0.5 \%<\mathrm{ROA} \leq 1.25 \%$ Quite Healthy (CS) 
- $0 \%<R O A \leq 0.5 \%$ Unwell (KS)

- $\mathrm{ROA}<0$ Not Healthy (TS)

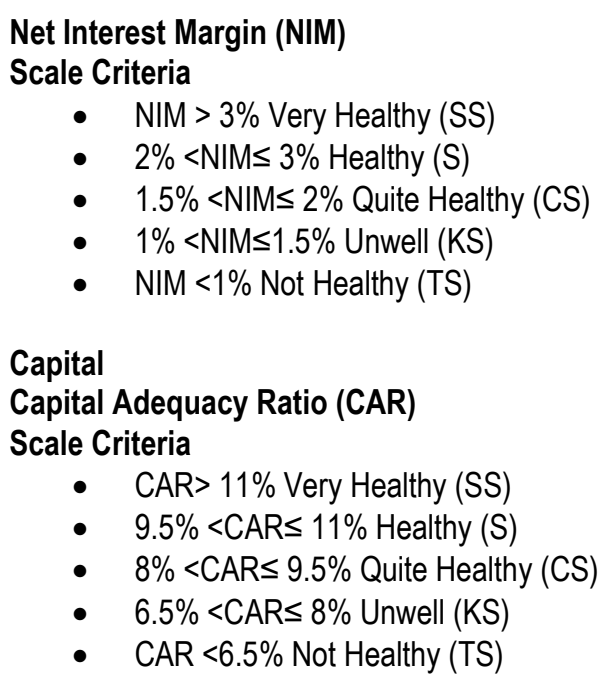

\section{RGEC Method (Risk Profile, Good Corporate Governance, Earning, Capital)}

Based on Bank Indonesia Regulation No. 13 of 2011 [14] Article 6, banks are required to evaluate the soundness of banks individually using a risk approach ( Risk-Based Bank Rating) and Financial Services Authority Circular number 14 / SEOJK.03 / 2017 dated March 17, 2017 concerning Rating of Commercial Bank Soundness in point III.1 Procedure for Assessing the Soundness of Commercial Banks Individually Assessment of Soundness Level of Commercial Banks Individually includes an assessment of risk profile factors , Governance, profitability and capital [1] with the scope of the assessment of the following factors:

1. Risk Profile (Risk Profile)

The formula used in calculating risk profiles is:

a. Non Performing Loans (NPL).

Net Performing Loans (NPL) are financing given to third parties (not including credit for other banks). The NPL ratio is calculated by comparing total financing with problems financing. The smaller the NPF ratio, the better asset quality [15].

NPL $=$ Non Performing Loan / Total Credit X 100\% [1].

b. Loan to Deposit Ratio (LDR)

LDR = Total Credit / Third Party Deposit X 100\% [1]

2. Good Corporate Governance (GCG)

Good Corporate Governance is a collection of laws, regulations and rules that must be fulfilled, which can encourage resources The Company works efficiently, generating economic value in the run sustainable length for shareholders and the public around as a whole [16].

3. Rentability (Earning)

Rentability can be calculated using a formula, namely:

a. Return On Asset (ROA)

ROA = Earnings before Tax / Average Asset Total X 100\%. [1]

b. Net Interest Margin (NIM)

NIM = Net Interest Income /Average Earning Assets X 100\% .[1]

Capital (Capital)

CAR Formula is as follows

CAR $=$ Risk Weighted Capital / Assets X $100 \%$ [1]

Hypothesis

$H_{1}$ : There are differences in performance bank of PT. Bank Mandiri Tbk since 2015 until 2018

\section{Object and Time of Research}

This research was conducted at of PT. Bank Tabungan Negara Tbk. The research time period is 2015 until 2018 . The data from secondary data at www.btn.co.id and www.ojk.go.id 


\section{Research Design}

This research is a kind of quantitative descriptive research. The focus of the research in this study is as follows:

- Performance bank at PT Bank Mandiri Tbk used the RGEC (Risk Profile, Good Corporate Governance, Earning, Capital) method approach.

- The research event study research to examine the information content based on a time series are 2015 until 2018 for PT Bank Mandiri Tbk, so that researchers can see the composite ranking since 2015 until 2018.

\section{RESULTS AND DISCUSION \\ Performance of PT. Bank Tabungan Negara (Persero) Tbk}

Performance of PT. Bank Tabungan Negara (Persero) Tbk as follow

Table-1: Performance Ratio of

\begin{tabular}{|l|r|r|r|r|}
\hline \multicolumn{5}{|c|}{ PT BANK TABUNGAN NEGARA (PERSERO). Tbk } \\
\hline & \multicolumn{5}{|c|}{ (In Prosentage) } \\
\hline Performance Ratio & $\mathbf{2 0 1 8}$ & $\mathbf{2 0 1 7}$ & \multicolumn{1}{c|}{$\mathbf{2 0 1 6}$} & \multicolumn{1}{c|}{$\mathbf{2 0 1 5}$} \\
\hline 1. Risk Profile & & & & \\
\hline a. Non Performing Loan (NPL) & 1.83 & 1.66 & 1.85 & 2.11 \\
\hline b. Loan to Deposit Ratio (LDR) & 103.25 & 103.13 & 102.66 & 108.78 \\
\hline 2. Good Corporate Governance (GCG) & 2 & 2 & 2 & 2 \\
\hline 3. Earning & & & & \\
\hline a. Return on Asset (ROA) & 1.34 & 1.71 & 1.76 & 1.61 \\
\hline b. Net Interest Margin (NIM) & 4.32 & 4.76 & 4.98 & 4.87 \\
\hline 4. Capital & & & & \\
\hline 1. Capital Adequacy Ratio (CAR) & 18.21 & 18.87 & 20.34 & 16.97 \\
\hline
\end{tabular}

Source : Otoritas Jasa Keuangan (2019)[15]

Based on table 1. Performance ratio of PT Bank Negara Indonesia (Persero) as follows

1. Risk Profile

a. Non Performing Loan (NPL) is performance ratio in 2015 of $2.11 \%$ mean healthy, Performance ratio in 2016 of $1.85 \%$ mean very healthy, Performance ratio in 2017 of $1.66 \%$ mean very healthy, performance ratio in 2018 of $1.83 \%$ mean very healthy.

b. Loan to Deposit Ratio (LDR) is performance ratio in 2015 of $108.78 \%$ mean unwell, Performance ratio in 2016 of $102.66 \%$ mean unwell, Performance ratio in 2017 of $103.13 \%$ mean unwell, Performance ratio in 2018 of 103.25 $\%$ mean unwell.

2. Good Coporate Governance (GCG).

Good Corporate Governance (GCG) is performance GCG in 2015 of 2 mean healthy, Performance GCG in 2016

of 2 mean healthy, performance ratio in 2017 of 2 mean healthy, Performance GCG in 2018 of 2 mean healthy.

3. Earning

a. Return on Assets (ROA) is performance ratio in 2015 of $1.61 \%$ mean very healthy, Performance ratio in 2016 of $1.76 \%$ mean very healthy, performance ratio in 2017 of $1.71 \%$ mean very healthy, Performance ratio in 2018 of $1.34 \%$ mean healthy.

b. Net Interest Margin (NIM) is Performance ratio in 2015 of 4.87\% mean very healthy, performance ratio in 2016 of $4.98 \%$ mean very healthy, Performance ratio in 2017 of $4.76 \%$ mean very healthy, performance ratio in 2018 of $4.32 \%$ mean very healthy.

4. Capital

Capital Adequacy Ratio (CAR) is performance ratio in 2015 of $16.97 \%$ mean very healthy, Performance ratio in 2016 of $20.34 \%$ mean very healthy, Performance ratio in 2017 of $18.87 \%$ mean very healthy, performance ratio in 2018 of $18.21 \%$ mean very healthy. 
Table-2: Performance Ratio Variance of

\begin{tabular}{|l|r|r|r|r|}
\hline \multicolumn{5}{|c|}{ PT BANK TABUNGAN NEGARA (PERSERO), Tbk } \\
\hline Performance Bank & 2018 & 2017 & 2016 & 2015 \\
\hline 1. Risk Profile & & & & \\
\hline a. Non Performing Loan (NPL) & $-0,28 \%$ & $-0,45 \%$ & $-0,26 \%$ & $0,00 \%$ \\
\hline b. Loan to Deposit Ratio (LDR) & $-5,53 \%$ & $-5,65 \%$ & $-6,12 \%$ & $0,00 \%$ \\
\hline 2. Good Corporate Governance (GCG) & 0 & 0 & 0 & 0 \\
\hline 3. Earning & & & & \\
\hline a. Return on Asset (ROA) & $-0,27 \%$ & $0,10 \%$ & $0,15 \%$ & $0,00 \%$ \\
\hline b. Net Interest Margin (NIM) & $-0,55 \%$ & $-0,11 \%$ & $0,11 \%$ & $0,00 \%$ \\
\hline 4. Capital & & & & \\
\hline 1. Capital Adequacy Ratio (CAR) & $1,24 \%$ & $1,90 \%$ & $3,37 \%$ & $0,00 \%$ \\
\hline
\end{tabular}

Source : Data processed (2019)

Based on Performance Ratio Variance of BNI with basic year of 2015 would show as follows

1. Risk Profil

a. Non Performing Loan (NPL) is performance ratio in 2016 decreased $-0.26 \%$, performance ratio in 2017 decreased $-0.45 \%$, and performance ratio in 2018 decreased $-0.26 \%$

b. Loan to Deposit Ratio (LDR) is performance ratio in 2016 decreased $-6.12 \%$, performance ratio in 2017 decreased $-5.65 \%$, and performance ratio in 2018 decreased $-5.53 \%$

2. Good Corporate Governance (GCG) that performance GCG is fixed and not difference since 2015 until 2018.

3. Earning

a. Return on Asset (ROA) is performance ratio in 2016 increased $0.15 \%$, performance ratio in 2017 increased 0.10 $\%$, and performance ratio in 2018 decreased $-0.27 \%$

b. Net Interest Margin (NIM) is performance ratio in 2016 increased $0.11 \%$, performance ratio in 2017 decreased 0.11 , and performance ratio in 2018 decreased $-0 . .55 \%$.

4. Capital

a. Capital Adequacy Ratio (CAR) is performance ratio in 2016 increased 3.37\%, performance ratio in 2017 increased $1.90 \%$, and performance ratio in 2018 increased $1.24 \%$

The Determinantion of Composite Ranking

Table-3: The Determination of Composite Ranking PT Bank Tabungan Negara In 2015

\begin{tabular}{|c|c|c|c|c|c|c|c|c|}
\hline \multirow[t]{3}{*}{ Ratio } & \multirow[t]{3}{*}{ Ratio Score } & \multicolumn{6}{|c|}{ Scoring Criteria } & \multirow[t]{3}{*}{ Description } \\
\hline & & Rank & 1 & 2 & 3 & 4 & 5 & \\
\hline & & Score & 5 & 4 & 3 & 2 & 1 & \\
\hline \multicolumn{9}{|c|}{ 1. Risk Profile } \\
\hline a. $\mathrm{NPL}$ & $2,11 \%$ & & & 4 & & & & Healthy \\
\hline b. LDR & $108,78 \%$ & & & & & 2 & & Unwell \\
\hline 2. GCG & 2 & & & 4 & & & & Healthy \\
\hline \multicolumn{9}{|l|}{ 3. Earning } \\
\hline a. $\mathrm{ROA}$ & $1,61 \%$ & & 5 & & & & & Very Healthy \\
\hline b. NIM & $4,87 \%$ & & 5 & & & & & Very Healthy \\
\hline \multicolumn{9}{|l|}{ 4. Capital } \\
\hline CAR & $16,97 \%$ & & 5 & & & & & Very Healthy \\
\hline \multicolumn{2}{|c|}{ Composite Rating $(\mathrm{A})$} & 25 & 15 & 8 & 0 & 2 & 0 & \\
\hline \multicolumn{2}{|c|}{ Composite Score (B) } & 30 & & & & & & \\
\hline \multicolumn{2}{|c|}{ Total Value $(\mathrm{A} / \mathrm{B})$} & 0,83 & \multicolumn{6}{|c|}{ Healthy } \\
\hline
\end{tabular}

Source : Data processed (2019)

Based on the determination of composite PT Bank Tabungan Negara in 2015 is the composite rating of 25, composite score of 30 results from 6 ratios multiple high score is 5 . Total value of composite of 0.83 mean the performance bank of PT Bank Tabungan Negara is Healthy 
Table-4: The Determination of Composite Ranking PT Bank Tabungan Negara In 2016

\begin{tabular}{|c|c|c|c|c|c|c|c|c|}
\hline \multirow{3}{*}{ Ratio } & \multirow[t]{3}{*}{ Ratio Score } & \multicolumn{6}{|c|}{ Scoring Criteria } & \multirow[t]{3}{*}{ Description } \\
\hline & & Rank & 1 & 2 & 3 & 4 & 5 & \\
\hline & & Score & 5 & 4 & 3 & 2 & 1 & \\
\hline \multicolumn{9}{|l|}{ 1. Risk Profile } \\
\hline a. NPL & $1,85 \%$ & & 5 & & & & & Very Healthy \\
\hline b. LDR & $102,66 \%$ & & & & & 2 & & Unwell \\
\hline 2. GCG & 2 & & & 4 & & & & Healthy \\
\hline \multicolumn{9}{|l|}{ 3. Earning } \\
\hline a. $\mathrm{ROA}$ & $1,76 \%$ & & 5 & & & & & Very Healthy \\
\hline b. NIM & $4,98 \%$ & & 5 & & & & & Very Healthy \\
\hline \multicolumn{9}{|l|}{ 4. Capital } \\
\hline CAR & $20,34 \%$ & & 5 & & & & & Very Healthy \\
\hline \multicolumn{2}{|c|}{ Composite Rating $(\mathrm{A})$} & 26 & 20 & 4 & 0 & 2 & 0 & \\
\hline \multicolumn{2}{|c|}{ Composite Score (B) } & 30 & & & & & & \\
\hline \multicolumn{2}{|c|}{ Total Value $(\mathrm{A} / \mathrm{B})$} & 0,87 & \multicolumn{6}{|c|}{ Healthy } \\
\hline
\end{tabular}

Source: Data processed (2019)

Based on the determination of composite PT Bank Tabungan Negara in 2016 is the composite rating of 26, composite score of 30 results from 6 ratios multiple high score is 5 . Total value of composite of 0.87 mean the performance bank of PT Bank Tabungan Negara is Healthy.

Table-5: The Determination of Composite Ranking PT Bank Tabungan Negara In 2017

\begin{tabular}{|c|c|c|c|c|c|c|c|c|}
\hline \multirow[t]{3}{*}{ Ratio } & \multirow[t]{3}{*}{ Ratio Score } & \multicolumn{6}{|c|}{ Scoring Criteria } & \multirow[t]{3}{*}{ Description } \\
\hline & & Rank & 1 & 2 & 3 & 4 & 5 & \\
\hline & & Score & 5 & 4 & 3 & 2 & 1 & \\
\hline \multicolumn{9}{|c|}{ 1. Risk Profile } \\
\hline a. NPL & $1,66 \%$ & & 5 & & & & & Very Healthy \\
\hline b. LDR & $103,13 \%$ & & & & & 2 & & Unwell \\
\hline 2. GCG & 2 & & & 4 & & & & Healthy \\
\hline \multicolumn{9}{|l|}{ 3. Earning } \\
\hline a. $\mathrm{ROA}$ & $1,71 \%$ & & 5 & & & & & Very Healthy \\
\hline b. NIM & $4,76 \%$ & & 5 & & & & & Very Healthy \\
\hline \multicolumn{9}{|l|}{ 4. Capital } \\
\hline CAR & $18,87 \%$ & & 5 & & & & & Very Healthy \\
\hline \multicolumn{2}{|c|}{ Composite Rating $(\mathrm{A})$} & 26 & 20 & 4 & 0 & 2 & 0 & \\
\hline \multicolumn{2}{|c|}{ Composite Score (B) } & 30 & & & & & & \\
\hline \multicolumn{2}{|c|}{ Total Value $(\mathrm{A} / \mathrm{B})$} & 0,87 & \multicolumn{6}{|c|}{ Healthy } \\
\hline
\end{tabular}

Based on the determination of composite PT Bank Tabungan Negara in 2017 is the composite rating of 26, composite score of 30 results from 6 ratios multiple high score is 5 . Total value of composite of 0.87 mean the performance bank of PT Bank Tabungan Negara is Healthy

Table-6: The Determination Of Composite Ranking PT Bank Negara In 2018

\begin{tabular}{|c|c|c|c|c|c|c|c|c|}
\hline \multirow[t]{3}{*}{ Ratio } & \multirow[t]{3}{*}{ Ratio Score } & \multicolumn{6}{|c|}{ Scoring Criteria } & \multirow[t]{3}{*}{ Description } \\
\hline & & Rank & 1 & 2 & 3 & 4 & 5 & \\
\hline & & Score & 5 & 4 & 3 & 2 & 1 & \\
\hline \multicolumn{9}{|c|}{ 1. Risk Profile } \\
\hline a. NPL & $1,83 \%$ & & 5 & & & & & Very Healthy \\
\hline b. LDR & $103,25 \%$ & & & & & 2 & & Unwell \\
\hline 2. GCG & 2 & & & 4 & & & & Healthy \\
\hline \multicolumn{9}{|l|}{ 3. Earning } \\
\hline a. ROA & $1,34 \%$ & & & 4 & & & & Healthy \\
\hline b. NIM & $4,32 \%$ & & 5 & & & & & Very Healthy \\
\hline \multicolumn{9}{|l|}{ 4. Capital } \\
\hline CAR & $18,21 \%$ & & 5 & & & & & Very Healthy \\
\hline \multicolumn{2}{|c|}{ Composite Rating (A) } & 25 & 15 & 8 & 0 & 2 & 0 & \\
\hline \multicolumn{2}{|c|}{ Composite Score (B) } & 30 & & & & & & \\
\hline \multicolumn{2}{|c|}{ Total Value $(\mathrm{A} / \mathrm{B})$} & 0,83 & \multicolumn{6}{|c|}{ Healthy } \\
\hline
\end{tabular}


Based on the determination of composite PT Bank Tabungan Negara in 2018 is the composite rating of 25, composite score of 30 results from 6 ratios multiple high score is 5 . Total value of composite of 0.83 mean the performance bank of PT Bank Tabungan Negara is Healthy

\section{CONCLUSION}

Based on result and discussion so the conclusion is performance bank of PT Bank Negara Indonesia (Persero) the value of determination or composite since 2015 until 2018 is healthy, and performance bank used RGEC method as follows:

1. Risk Profile are a). Non Performing Loan (NPL) is in 2015 is healthy, NPL in 2016 is very healthy, NPL in 2017 is very healthy, NPL in 2018 is very healthy. b) Loan to Deposit Ratio (LDR) is in 2015 unwell, LDR in 2016 is unwell, LDR in 2017 is unwell, LDR in 2018 is unwell.

2. Good Corporate Governance (GCG) is performance GCG in 2015 is healthy, GCG in 2016 is healthy, GCG in 2017 is healthy, GCG in 2018 is healthy.

3. Earning are a) Return on Assets (ROA) is RAO in 2015 is very healthy,ROA in 2016 is very healthy, ROA in 2017 is very healthy, ROA in 2018 is healthy. b) Net Interest Margin (NIM) is NIM in 2015 is very healthy; NIM in 2016 is very healthy, NIM in 2017 is very healthy, in 2018 is very healthy.

4. Capital for Capital Adequacy Ratio (CAR) is in 2015 is very healthy, CAR in 2016 is very healthy CAR in 2017 is very healthy; CAR in 2018 is very healthy.

\section{REFERENCES}

1. Otoritas Jasa Keuangan. (2017). Surat Edaran Otoritas Jasa Keuangan nomor 14/SEOJK.03/2017 tanggal 17 Maret 2017 tentang Penilaian Tingkat Kesehatan Bank Umum www.ojk.go.id)/id/regulasi/Surat-Edaran-OJK>Pages

2. Christian. F. J, Tommy. P \& Tulung. J (2017). Bank Health Analysis Using RGEC Method in BRI and Mandiri Bank, Jurnal EMBA, 5(2). 530-540

3. Sukarno, P.A (2018). BTN Sabet Predikat Bank Terbaik 2018, Simak Lompatan Prestasi Bank Tabungan Negara. Diungah 02 Juli 2018.05:28. www.

4. Bisnis.com Ahmad, B.R. (2018). Inilah Para Pemenang Indonesia Best Banking Award 2018. Diungah Jumat 30 November 2018 20:06 WIB, www.wartaekonomi.co.id

5. Riadi, K.S., Atmadja, A.T., \& Wahyuni M.A. (2016). Penilaian Tingkat Kesehatan Bank dengan menggunakan metode RGEC (Risk Profile, Good Corporate Governance, Earnings, dan Capital) pada PT. Bank Mandiri (Persero), Tbk periode 2013-2015, JIMAT (Jurnal Imiah Mahasiswa Akuntansi). E-Journal S1 Ak. Universitas Pendidikan Ganesha. 6(3).

6. Kusnanto, A. (2017). Risk Profile, Good Corporate Governance, Earning, Capital (RGEC) Method sebagai Instrumen Pengukur Tingkat Kesehatan Perbankan Syariah di Indonesia, Jurnal Administrasi Bisnis, 6(2):124-136.

7. Rahmaniah, M., \& Wibowo, H. (2015). analisis potensi terjadinya financial distress pada bank umum syariah (BUS) di Indonesia. Jurnal Ekonomi dan Perbankan Syariah, 3(1), 1-20.

8. Helsinawati, Widyanto, M, L., \& Faizal., H. (2018). Impact Analysis: Before and After Branchless Banking Implementation towards the Bank's Financial Performance (Case Study on PT Bank Bukopin, Tbk). Saudi Journal of Business and Management Studies (SJBMS). 3(6): 670-680

9. Widyanto. M, L. (2019). Comparative Analysis Implementation of Circular Letters Financial Services Authority Number 14/ Seojk.03/2017 Concerning Assessment of The Soundness Level of Regional Development Banks (Case Study at Bank DKI and BPD Jawa Tenggah, Saudi Journal of Business and Management Studi, 4(4): 297-305.

10. Permana, D. (2017). Toward the Best Model of Strategy Implementation in Indonesian Islamic Banking from the Lens of Strategic Clarity, European Research Studies Journal. 20(4B).2017:3-15

11. Fitrawati, Saifi, M., \& Zahroh. (2016). Penerapan Aplikasi RGEC (Risiko Profil, Tata Kelola Perusahaan yang Baik, Penghasilan, Modal) dalam Bank Kinerja Menganalisis Untuk Mengetahui Tingkat Kesehatan Bank (Studi Kasus PT. Bank Tabungan Negara (Persero) Tbk. Periode 2013-2015). Jurnal Administrasi Bisnis, 37(1):30.

12. Bank Indonesia. (2011). Surat Edaran Nomor.13 / 24 / DPNP / 2011,www.bi.go.id

13. Bank Indonesia. (2013). Surat Edaran Nomor. 15/15 / DPNP of 2013,www.bi.go.id

14. Bank Indonesia. (2011). Peraturan Bank Indonesia Tentang Penilaian Tingkat Kesehatan Bank Bank Umum, dengan nomor regulasi 13/1/PBI/2011 tanggal 5 Januari 2011 www.ojk.go.id)>Documents>pages>Salinan-POJK4-Penilaian-10.pdf

15. Hadisoewito. S. (2011). Prinsip Dasar Kehati-hatian dan Penilaian Bank. Jakarta: Pamato

16. Arafat, W. (2006). Manajemen Perbankan Indonesia, Teori dan Implementasi. Jakarta: Pustaka LP3ES Indonesia.

17. Otoritas, Jasa, Keuangan. (2019). Laporan Perbankan PT Bank Tabungan Negara (Persero) Tbk, www.ojk.go.id. 